\title{
A abordagem CLIL na graduação em Letras/Alemão: pontes possíveis
}

\author{
[The CLIL approach in German undergraduate studies: possible bridges] \\ http://dx.doi.org/10.11606/1982-88372546172
}

Marina Grilli ${ }^{1}$

\begin{abstract}
This paper revisits the author's master's research (GRILLI 2018) and aims to explore the concept of Content and Language Integrated Learning (CLIL) and its possible applications in Brazilian undergraduate German studies. The first section sums up the history of what we call bilingual education and the main features of the CLIL approach. In the second section the Brazilian reality is outlined, namely the guidelines for bilingual education and for German undergraduate courses in our country. Greater focus is given to the University of São Paulo, scene of an empirical research about the difficulties perceived by graduates throughout the course, described and discussed in this paper. The results of the study make room for the discussion on how to link CLIL theory and the reality of German undergraduate studies in Brazil, by relating the five dimensions of CLIL and Bloom's taxonomy to the curriculum of such courses. Finally, it is argued that a work based on the CLIL approach can give undergraduate students greater autonomy in the use of the German language in all its dimensions, and, consequently, greater autonomy in their future work as teachers.
\end{abstract}

Keywords: CLIL; German undergraduate studies; German as additional language; German in a university context.

Resumo: Este trabalho retoma pontos da pesquisa de mestrado da autora (GRILLI 2018) e tem como objetivo explorar o conceito de Ensino Integrado de Língua e Conteúdo (CLIL) e suas possíveis aplicações nos cursos de graduação em Letras/Alemão brasileiros. Na primeira seção, são apresentadas a história daquilo a que chamamos ensino bilíngue e as principais características da abordagem CLIL. Na segunda seção, voltada à realidade brasileira, são recuperadas as diretrizes que regem a educação bilíngue em nosso país, e os documentos que regem os cursos de Letras/Alemão. Maior foco é conferido à USP, instituição na qual foi realizada a pesquisa empírica aqui descrita e discutida, que se ocupa das dificuldades percebidas ao longo do curso por egressos. Após apresentar os resultados da pesquisa, discute-se como unir a teoria do CLIL à realidade dos cursos de Letras/Alemão no Brasil, relacionando as cinco dimensões do CLIL e a taxonomia de Bloom à grade curricular desses cursos. Na conclusão, defende-se que um trabalho baseado na abordagem CLIL pode conferir aos graduandos maior autonomia no uso da língua alemã em todas as suas dimensões, e, consequentemente, maior autonomia em seu futuro trabalho docente.

Palavras-chave: CLIL; graduação em Letras; alemão como língua adicional; alemão em contexto universitário.

\footnotetext{
${ }^{1}$ Universidade de São Paulo, Departamento de Letras Modernas, Avenida Luciano Gualberto, 403, Cidade Universitária, São Paulo, SP, 05508-900, Brasil. E-mail: marina.grilli.silva@usp.br. ORCID: 0000-00026324-7030.
}

A pesquisa de mestrado que deu origem a este artigo foi realizada com bolsa CAPES.

(cc) BY-NC

Pandaemonium, São Paulo, v. 25, n. 46, mai.-ago. 2022, p. 172-201 


\section{Introdução}

Em conjunto com colégios bilíngues privados acessíveis a uma pequena parcela da população, e com escolas bilíngues situadas em antigas regiões de imigração alemã, os cursos de graduação em Letras/Alemão constituem um dos poucos contextos em potencial em que o Ensino Integrado de Língua e Conteúdo (CLIL) em alemão pode ter espaço no Brasil. Por mais que os currículos desses cursos de graduação sejam muito diferentes de uma universidade para outra, quase todos eles compartilham um ponto em comum: a dificuldade enfrentada pelos alunos quando da transição das aulas de língua, em que geralmente se chega a um nível de conhecimento entre B1 e B2, para as de literatura, para as quais devem ser lidas obras clássicas no original em alemão.

Em trabalho anterior (GRILLI 2019), descreveu-se uma investigação empírica que envolveu questionários, testes de leitura e entrevistas com alunos de uma disciplina da Licenciatura em Letras/Alemão da USP, intitulada Aquisição/Aprendizagem do Alemão como Língua Estrangeira, que se encaixa nas diretrizes do CLIL.

Alguns resultados dessa pesquisa mostraram que a competência de leitura dos alunos foi beneficiada, levando à conclusão de que o trabalho com a abordagem CLIL na formação de profissionais brasileiros de Letras/Alemão é capaz de oferecer novas perspectivas no sentido de atenuar o impacto negativo da transição das aulas de língua para as de literatura (Cf. UPHOFF \& DEBIA 2017).

Aqui, essas reflexões serão expandidas: considerando as características que configuram a abordagem de Ensino Integrado de Língua e Conteúdo, aquela disciplina naturalmente não é a única que pode se enquadrar no espectro de disciplinas bilíngues dos cursos de graduação em Letras/Alemão no Brasil. Afinal, a presença da L1 atravessa muitas outras disciplinas da grade curricular: além das desafiadoras disciplinas de literatura, existem ainda os blocos de conteúdo relativos à tradução, à linguística e à cultura dos países germanófonos, além das disciplinas de didática, típicas de um curso de licenciatura.

Para tanto, este trabalho explora mais a fundo o que é o CLIL, contrapondo a história da abordagem conforme desenvolvida nos países hegemônicos com a realidade brasileira. A seguir, voltamo-nos para o ensino universitário de alemão enquanto rico contexto de trabalho com a abordagem CLIL. Após apresentar resultados de uma pesquisa 
GRILLI, M. - A abordagem CLIL na graduação em Letras/Alemão

empírica realizada com graduados em Letras/Alemão na USP, discute-se como unir a teoria do CLIL à realidade dos cursos de Letras/Alemão no Brasil.

Assim, faz-se um movimento no sentido de responder à demanda, observada por Megale \& Liberali (2016: 21), de "estudos sobre o currículo de Letras e de educação e sua relação com questões multilíngues" no cenário brasileiro.

\section{$2 \bigcirc \mathrm{CLIL}$}

CLIL é a sigla para Content and Language Integrated Learning, isto é, Ensino Integrado de Língua e Conteúdo. Antes de entrar nas características da abordagem, é interessante retomar a história do ensino bilíngue. A primeira subseção a seguir faz essa retomada histórica, e a segunda ocupa-se das especificidades que caracterizam o CLIL.

\subsection{A História do ensino bilíngue como o conhecemos}

Em primeiro lugar, faz-se necessário reforçar que falar em "ensino bilíngue como o conhecemos" significa optar pelo reconhecimento de que, apesar de o plurilinguismo e o multilinguismo ${ }^{2}$ serem e terem sido fenômenos comuns em todo o mundo e em todas as épocas, a colonização europeia justificada pelos princípios da chamada Modernidade trabalhou no sentido de associar cada língua a um Estado e a uma cultura (KRAMSCH 2014, Mignolo 2011).

Por esse motivo, alguns poucos países do Norte global dominam a narrativa acerca da educação bilíngue, não havendo hoje qualquer registro sistematizado dessa prática em sociedades denominadas indígenas ou aborígenes - tampouco nas avançadas sociedades pré-modernas, como a egípcia e a asteca (Cf. MignOLO 2011: 4).

Então, o que se entende por ensino bilíngue hoje? ${ }^{3}$ Segundo Vollmer (2010: 124), não há um consenso a respeito da definição desse termo, nem na Alemanha, nem muito menos em toda a Europa - e certamente não há também um consenso em regiões do globo

\footnotetext{
${ }^{2}$ Uma acepção comum do termo plurilinguismo é a capacidade individual de se comunicar em mais de uma língua, enquanto multilinguismo se refere à coexistência de línguas em um mesmo meio social (cf. NEUNER et al. 2009: 17).

${ }^{3}$ Neste artigo, os termos educação e ensino são empregados como sinônimos, pois uma reflexão sobre os pressupostos que diferenciam ambos foge ao escopo deste trabalho.
}

Pandaemonium, São Paulo, v. 25, n. 46, mai.-ago. 2022, p. 172-201 
GRILLI, M. - A abordagem CLIL na graduação em Letras/Alemão

onde o ensino bilíngue é menos praticado, sistematizado e discutido, como é o caso do Brasil.

Quando do surgimento do ensino bilíngue na Alemanha, na década de 1960, não havia um suporte teórico específico para a prática. Entre as décadas de 1980 e 1990, o ensino bilíngue passou a ser visto, sob a perspectiva da didática de LE, como contraposição às concepções estruturalistas de aula e aos métodos audiolingual e audiovisual.

Nos anos 1990, a onda comunicativa culminou no modelo de imersão como ideal para o ensino de LE, por trabalhar com objetos de ensino autênticos, o que colocou a educação para o bilinguismo em evidência (Cf. WOLFF 2013: 14, BREIDBACH, 2013: 1314). Assim, no século XXI, o Ensino Integrado de Língua e Conteúdo, também conhecido como ensino bilíngue, foi deixando de ser uma exceção e consolidando-se como parte do sistema de ensino europeu.

Mello (2010: 119s) aponta ainda que nem sempre se tem clareza sobre o que é um programa de ensino bilíngue e o que se espera dele: muitas nomenclaturas e termos são empregados para fazer referência a uma mesma tipologia. No âmbito do ensino escolar, a autora (MELLO 2010: 120-21) distingue majoritariamente entre a educação bilíngue transicional e a de manutenção, sendo a primeira aquela em que a instrução na L1 do aluno acontece somente até que a criança consiga acompanhar as aulas em na língua adicional $^{4}$, e a segunda, a que busca preservar o contato do aluno com sua L1 no ambiente escolar.

Porém, se observarmos os pressupostos que embasam ambos os modelos de ensino bilíngue sob uma perspectiva que considere seu papel no(s) contexto(s) de um país localizado no Sul global (Cf. LiBERALI 2020), notamos que ambas as abordagens de ensino bilíngue são baseadas na ideia de que a língua-alvo possui um valor maior do que a língua materna de quem a aprende: tanto a repressão da língua materna como a tolerância de sua presença representam uma postura de pretensa superioridade da línguaalvo. Em outras palavras, a L1 passa por um processo de desvalorização ao ser ora reprimida, ora menosprezada, na aula da língua adicional (Cf. GRILLI 2020).

\footnotetext{
${ }^{4}$ Optamos por substituir o termo "língua estrangeira" pelo termo "língua adicional", que tem sido utilizado no sentido de retirar a carga semiótica do termo "estrangeiro" como algo vindo de fora, visto que as fronteiras entre paisagens linguísticas estão cada vez mais tênues.
} 
GRILLI, M. - A abordagem CLIL na graduação em Letras/Alemão

Outra categoria de classificação é a imersão estruturada, programa em que não ocorre um ensino bilíngue de fato, e sim, monolíngue, mas no qual os alunos "tornam-se bilíngues à medida que usam na escola uma língua diferente daquela que é falada regularmente em casa". Nesse tipo de programa, a L1 pode ser usada pelos alunos, mas não é empregada na aula em caráter oficial; uma variação consiste em incorporar ao programa regular monolíngue algum tipo de suporte linguístico ou acadêmico (MELLO 2010: 120).

Alguns pesquisadores ainda mencionam a falta de orientações didáticometodológicas para a prática do ensino bilíngue, baseadas não só em modelos teóricos, mas em pesquisa empírica: segundo Schmelter (2013: 43), a seleção de conteúdos disciplinares que leve em consideração as competências bilíngue e intercultural do aprendiz só é possível a partir da cooperação entre ambas as perspectivas. Essa cooperação se faz urgente no estabelecimento dos chamados andaimes sobre os quais o aprendiz possa se apoiar na construção de competências para dominar o conteúdo em ambas as línguas. Voltaremos ao conceito de andaimes na seção 2.2.1.

O conceito de Ensino Integrado de Língua e Conteúdo só veio a ser nomeado durante a década de 1990, ao mesmo tempo em que se multiplicavam os ambientes escolares em conformidade com a abordagem CLIL em todas as suas variações (HAATAJA \& WiCKE 2015: 9). Hoje, o CLIL é visto como problemática inerente à Psicologia Cognitiva, e dele se desdobram duas linhas de argumentação principais: os aspectos da aquisição de língua integrada à aprendizagem de conteúdo e a interculturalidade, enquanto integração, aliada à Sociopragmática e às teorias construtivistas (BREIDBACH 2013: 15).

Porém, ainda não têm sido suficientemente considerados, nas pesquisas e reflexões sobre a abordagem, os elos teóricos entre língua e conhecimento, bem como a estrutura dos processos de aprendizagem de conteúdos específicos (BREIDBACH 2013: 15). Isso significa que ainda há muito espaço para explorar o CLIL.

\subsection{Características da abordagem CLIL}

Neste tópico, trataremos de características escolhidas da abordagem CLIL, relevantes para a análise e discussão de dados que será realizada em seguida. 
GRILLI, M. - A abordagem CLIL na graduação em Letras/Alemão

O primeiro ponto que deve ser reforçado ao falarmos de CLIL é que não se trata do ensino de conteúdo disciplinar em outra língua, mas, sim, do ensino de conteúdo disciplinar com outra língua, ou através de outra língua (EURYDICE 2006: 8 apud MARSH, 2008: 233). Esse esclarecimento se faz necessário na medida em que o ensino bilíngue tem suas especificidades, não se tratando de uma proposta de ensino monolíngue em outra língua.

\subsubsection{Scaffolding e a Taxonomia de Bloom}

O ensino bem-sucedido de língua e conteúdo em conjunto exige, acima de tudo, um cuidadoso planejamento - afinal, "além de ensinar o conteúdo por meio de outra língua, deve-se também ensinar língua - estruturas linguísticas e discursivas que permitam ao aluno discorrer e manipular o conteúdo específico" (MEGALE 2020: 18).

Em escolas que trabalham com o ensino bilíngue, é necessário que os momentos de planejamento em equipe façam parte da carga horária de trabalho docente. Já no ensino bilíngue universitário, as disciplinas de língua podem assumir o papel de mediar língua e conteúdo, por três motivos:

- a graduação em Letras não é um curso de língua, de modo que as disciplinas de língua têm como objetivo prover insumos para que o graduando se torne capaz de "refletir sobre os fatos linguísticos e literários" (РROJETO 2013);

- o conteúdo trabalhado no curso é relativo às propriedades da língua em si, constituindo assim um contexto CLIL metalinguístico;

- é esperado um maior grau de autonomia dos alunos de graduação do que nos níveis de ensino anteriores, tornando a mediação entre a língua e o conteúdo metalinguístico uma responsabilidade compartilhada entre docentes e graduandos.

Um dos princípios centrais do CLIL é a criação de um ambiente de vivência na língua-alvo, no qual, além da aquisição do conhecimento formal sobre a língua, se tenha oportunidades de uso da linguagem técnica geral e específica da disciplina (HAATAJA \& WICKE 2016: 4).

Um tal ambiente de vivência interativa está de acordo com os princípios da Teoria Sociocultural vygotskyana, segundo a qual o indivíduo internaliza as representações mentais de seu grupo social por meio de interações. Representação é palavra-chave aqui: 
GRILLI, M. - A abordagem CLIL na graduação em Letras/Alemão

ensinar, portanto, é criar representações significativas, e aprender é engajar-se nessas representações significativas. Em outras palavras, ensinar não é sinônimo de tornar conscientes os alunos, e sim, de fornecer modelos para que eles possam criar suas próprias representações (NEGUERUELA-AZAROLA 2010).

Outro conceito crucial elaborado por Vygotsky é o de zona de desenvolvimento proximal: trata-se da distância entre o estágio atual de desenvolvimento de um indivíduo, demonstrado por sua capacidade de resolver problemas de modo independente, e o nível de desenvolvimento potencial desse mesmo indivíduo, demonstrado por sua capacidade de resolver problemas com o auxílio de um professor ou colega mais avançado (HALL 2002).

Esse apoio ou auxílio que o aprendiz recebe para realizar as tarefas que ainda não é capaz de realizar sozinho é chamado scaffolding. Naturalmente, scaffolding é fundamental no trabalho com o CLIL: por meio do apoio, o aprendiz é levado a construir conhecimento sobre o conteúdo disciplinar e a desenvolver sua linguagem, tornando-se capaz de utilizar a linguagem para criar suas próprias representações do conteúdo e para comunicar-se sobre ele.

Algumas estratégias de scaffolding propostas por Hall (2002) incluem chamar a atenção, reduzir o grau de liberdade, direcionar a atenção, enfatizar características, reduzir a frustração e modelar o comportamento esperado. O trecho reproduzido na Figura 1 exemplifica o uso de estratégias de scaffolding em um diálogo com uma criança.

Figura 1. Exemplo de diálogo com estratégias de scaffolding para aquisição de língua

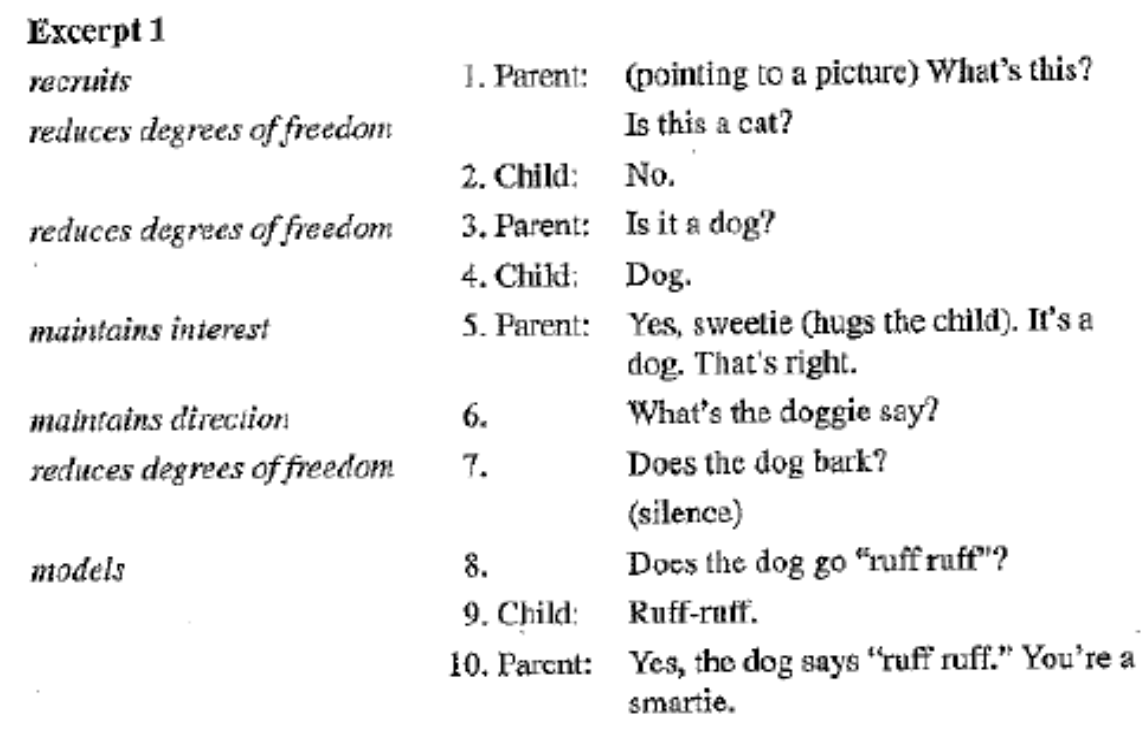

Fonte: Hall (2002: 32)

Pandaemonium, São Paulo, v. 25, n. 46, mai.-ago. 2022, p. 172-201 
GRILLI, M. - A abordagem CLIL na graduação em Letras/Alemão

Mesmo sem esquecermos que a aquisição de língua por uma criança é, em muitos aspectos, diferente da aprendizagem de língua por adultos matriculados em um curso de graduação, o exemplo é válido para demonstrar como o apoio passo-a-passo propiciado pelas técnicas de scaffolding é capaz de levar à construção de conhecimento.

Mais do que isso, o scaffolding fornece modelos aos aprendizes para que eles criem suas próprias representações, conforme a definição vygotskyana de aprendizagem. Em outras palavras, é objetivo central do CLIL superar as habilidades de pensamento de ordem inferior [lower-order thinking skills, LOTS] e alcançar o desenvolvimento das habilidades de pensamento de ordem superior [higher-order thinking skills, HOTS] (MARSH 2008).

As habilidades de pensamento foram organizadas por Benjamin Bloom (1956) na Taxonomia de Objetivos de Aprendizagem, que ficou conhecida como Taxonomia de Bloom. De acordo com sua versão revisada (ANDERSON \& KRATHWOHL 2001), são seis os níveis de aprendizagem, representados pelos seguintes verbos, do mais simples ao mais complexo: lembrar, compreender, aplicar, analisar, avaliar e criar.

A Taxonomia de Bloom é comumente representada por uma pirâmide, dividida em seis camadas. A cada um dos níveis da pirâmide, correspondente a um verbo-chave, relaciona-se uma série de verbos específicos, que são úteis para determinar os objetivos de cada etapa da aprendizagem ao planejar aulas e sequências didáticas. A Figura 2 representa os níveis da pirâmide e traz alguns dos verbos relacionados a cada nível da taxonomia.

Figura 2. Pirâmide representativa da taxonomia de Bloom

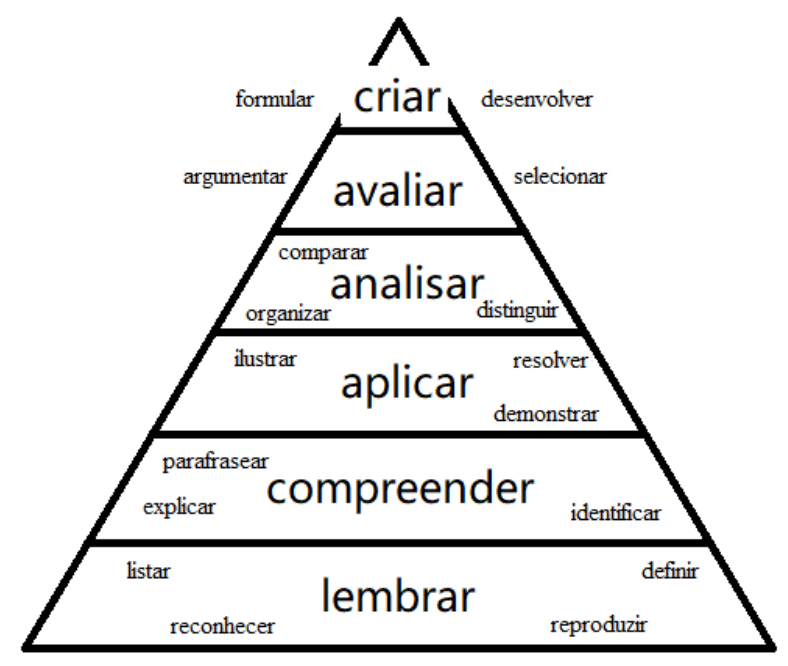

Fonte: adaptado de Anderson \& Krathwohl (2001) 
GRILLI, M. - A abordagem CLIL na graduação em Letras/Alemão

São consideradas habilidades de pensamento de ordem inferior as três primeiras, e superior, as três últimas. Ou seja: ser capaz de retomar conceitos armazenados na memória, explicar do que se trata e utilizá-los na resolução de tarefas simples envolveriam menor complexidade de pensamento do que estabelecer conexões entre conceitos, usar essas conexões para embasar uma decisão ou elaborar um modo original de empregá-los no cotidiano.

Hanesová (2014: 35) observa que as mais recentes descobertas científicas não provam haver diferenças entre a complexidade das habilidades de pensamento de ambos os tipos, indicando que todas elas são relativamente independentes umas das outras. Porém, a nomenclatura LOTS/HOTS é denominador comum entre profissionais que trabalham com o CLIL, servindo inclusive para distinguir entre tarefas que o aprendiz consegue realizar sozinho ou apenas com ajuda, e será empregada como pressuposto teórico neste artigo.

\subsubsection{As cinco dimensões do CLIL}

David Marsh (2008: 240-241) classifica cinco dimensões do CLIL, identificadas em um estudo realizado em diversos países da Europa (MARSH, MALJERS \& HARTIALA 2001). As dimensões se complementam, e sua implementação varia de acordo com a faixa etária dos aprendizes e seu grau de exposição ao CLIL, bem como o contexto sociolinguístico em que ocorre a aprendizagem.

A dimensão da cultura refere-se à construção de conhecimento intercultural, incluindo habilidades de comunicação com grupos culturais não-hegemônicos e minoritários.

A dimensão do ambiente engloba o preparo para a internacionalização do aprendiz, por meio do acesso a certificações internacionais e do estímulo à construção de um perfil escolar de instituição internacional.

A dimensão da linguagem refere-se não só ao desenvolvimento de habilidades de comunicação oral, mas também da consciência acerca do próprio conhecimento linguístico e do próprio uso da língua, além do desenvolvimento de interesses e atitudes plurilíngues. 
GRILLI, M. - A abordagem CLIL na graduação em Letras/Alemão

A dimensão do conteúdo ocupa-se de conferir acesso à terminologia específica da língua-alvo, e também de criar oportunidades para aproximar-se do conteúdo por meio de diferentes perspectivas, preparando para futuros estudos ou oportunidades de trabalho.

Por fim, a dimensão da aprendizagem abrange o ensinar a aprender, isto é, o complemento a estratégias individuais de aprendizagem, bem como o trabalho com a motivação do aprendiz e a diversificação de métodos e de práticas em sala de aula.

As cinco dimensões não estão entre as características do CLIL mais comumente exploradas por estudiosos da abordagem. Optamos por inclui-las neste trabalho a fim de refletir sobre sua presença nas disciplinas dos cursos de Letras/Alemão, já que a formação do futuro profissional da área não pode prescindir de qualquer uma delas.

\section{Ensino bilíngue ou monolíngue?}

No Brasil, a aula CLIL em língua alemã é encontrada majoritariamente em dois contextos: em colégios bilíngues particulares, cujo público pertence tradicionalmente às classes sociais mais altas, e em universidades públicas que oferecem cursos de Bacharelado ou Licenciatura em Letras com habilitação em Alemão. Escolas em regiões de imigração, onde se fala e se ensina o alemão padrão e/ou uma variante regional da língua e oferecem conteúdo disciplinar parcialmente bilíngue, são minoria em nosso país e situam-se quase que exclusivamente na região Sul (Cf. FRITZEN 2008, 2013, PupP SPINASSÉ 2005, 2006, entre outros).

Assim, no contexto do bilinguismo de escolha que envolve línguas de prestígio, o ensino bilíngue acabava adquirindo as feições de um ensino monolíngue na língua-alvo, isto é, na língua de prestígio: nos colégios bilíngues de elite, o discurso empregado para atrair famílias remete a uma vida melhor em um país hegemônico, dando a entender que é mais importante preparar o aluno para um futuro a ser vivenciado na língua adicional de prestígio do que em sua língua materna.

Essa postura deve sofrer mudanças com a homologação do Parecer CNE/CEB n 2/2020, que define as Diretrizes Curriculares Nacionais para a oferta de Educação Plurilíngue (BRASIL 2020). Segundo o documento, a instrução na língua adicional deve abranger de $30 \%$ a $50 \%$ da carga horária total para a Educação Infantil e o Ensino Fundamental, e um mínimo de 20\% no Ensino Médio. Desse modo, será possível atingir 
GRILLI, M. - A abordagem CLIL na graduação em Letras/Alemão

nas escolas ditas bilíngues uma educação verdadeiramente bilíngue, de manutenção, e não transicional ou de subtração.

Ofélia García (2009), uma das maiores pesquisadoras do ensino bilíngue no mundo, reforça que uma proposta de educação bilíngue deve ser pensada para além dos tradicionais programas de escolas bilíngues que separam rigidamente os momentos e espaços de uso de cada língua, numa postura a que chama monoglóssica. O caminho, segundo a autora, é aproximarmo-nos de uma postura heteroglóssica, isto é, que reconheça a multiplicidade de práticas linguísticas que convivem em uma mesma comunidade de fala.

As seções a seguir tratam dos aspectos curriculares da graduação em Letras/Alemão no Brasil e, mais especificamente do curso de Letras/Alemão da USP, contexto em que foi realizada a pesquisa empírica relatada na seção 3.2.3.

\subsection{Aspectos curriculares do ensino universitário de alemão}

Em 16 das 17 Instituições de Ensino Superior brasileiras que oferecem a graduação em Letras com habilitação em Alemão, o ensino da língua tem início no nível A1, o que significa que saber a língua não é pré-requisito para ingressar no curso. A única instituição que tem o conhecimento de língua como pré-requisito é o Instituto de Formação de Professores de Língua Alemã (IFPLA), localizado em Ivoti, no Rio Grande do Sul, uma região que guarda estreitos laços com a língua e a cultura alemã desde o período da imigração alemã para o Brasil.

Embora essa medida propicie oportunidades de acesso e de desenvolvimento a muito mais calouros do que aqueles que já têm conhecimento do alemão, parte do currículo fica comprometida com o ensino da língua, e é comum que futuros professores não atinjam um nível adequado de proficiência. De fato, as Diretrizes Curriculares Nacionais para o curso de Letras (BRASIL 2001) deixam “a cargo da Instituição de Ensino Superior definições como perfil profissional, carga horária, atividades curriculares básicas, complementares e de estágio". Porém, no caso das Licenciaturas, o artigo 65 da Lei 9.394/96 (BRASIL 1996), conhecida como Lei de Diretrizes e Bases da Educação Nacional, institui um mínimo de trezentas horas para a prática de ensino, que devem ser inclusas na carga horária dos cursos superiores de formação docente. Essa prática é retomada na Resolução CNP/CP n 1 de 2002 (BRASIL 2002a), que detalha o "preparo 
GRILLI, M. - A abordagem CLIL na graduação em Letras/Alemão

para o exercício profissional específico" estabelecendo metas para a prática docente no âmbito do estágio e, de forma abrangente, permeando o curso como um todo.

Outros dois documentos que regulamentam os cursos de Licenciatura no Brasil são a resolução CNP/CP n 2 de 2002 (BRASIL 2002b), que aumenta para quatrocentas as horas de estágio curricular supervisionado obrigatório e institui a Prática como Componente Curricular integrada à grade do curso, e o parecer CNE/CP $\mathrm{n}^{\circ} 9$ de 2001 (BRASIL 2001), que apresenta críticas à LDB no sentido de que esta isola as instituições de formação de professores dos contextos em que se inserem, desconsidera o repertório de conhecimento dos professores em formação, não expressa claramente os conteúdos que o professor em formação deve aprender, apresenta uma concepção restrita de "prática" e não dispõe sobre o desenvolvimento cultural desses futuros professores, entre outros motivos.

Esses problemas são parcialmente contornados com o estabelecimento da Prática como Componente Curricular em 2002 (BRASIL 2002b), que fornece uma orientação mais precisa para o desenvolvimento profissional, incluindo as competências a serem desenvolvidas na formação da educação básica, separadas entre diversas fontes de conhecimento. A esse respeito, Paiva (2005, s/p) aponta que

[...] ]as diretrizes para o curso de Letras, aprovadas em 03 de abril de 2001, afirmam que os cursos de graduação em Letras deverão ter estruturas flexíveis que facultem ao profissional a ser formado opções de conhecimento e de atuação no mercado de trabalho $[\ldots]$.

Quanto aos bacharéis em Letras, Paiva (2005) reforça que se espera as competências e habilidades necessárias para o trabalho como "professores, pesquisadores, críticos literários, tradutores, intérpretes, revisores de textos, roteiristas, secretários, assessores culturais, entre outras atividades" (BRASIL 2001: 30).

Vamos ver como esses fatores se relacionam no curso de graduação em Letras/Alemão da USP.

\subsection{Breve histórico do curso de Letras/Alemão na USP}

O Curso de Letras Anglo-Germânicas da USP, em que se estudavam língua e literatura alemã, inglesa e estadunidense, teve início no ano de 1940. Além de dificuldades específicas do período de guerra, como a dificuldade de acesso a materiais didáticos e a livros importados da Alemanha de modo geral, bem como a necessidade de passar ao 
largo de temas políticos ao trabalhar literatura e cultura alemãs, outro entrave no curso já naquela época - era a ausência de conhecimentos prévios da língua, o que fez com que as disciplinas de literatura passassem a ser ministradas somente a partir do segundo ano da graduação (UPHOFF, LOBATO \& SAFRA 2014).

A partir de 1964, há registros de que o ciclo das disciplinas de literatura passou a ser iniciado pela literatura do século XX, antes do estudo dos autores do século XIX (UPHOFF \& PEREZ 2015: 15-16). Nos dias de hoje, o estudo da literatura só tem início no terceiro ano da graduação, mas o conhecimento insuficiente da língua quando do início das disciplinas de literatura permanece como um obstáculo, conforme será mencionado mais adiante.

Já na década de 1990, autores como Nomura (1991) defendiam a inclusão de outros tipos de textos que não os literários no currículo da graduação em Letras: "todas as tipologias de textos, antigos ou novos, para fins estéticos ou pragmáticos, que constituem o acervo dos povos em todos os seus níveis" (NOMURA 1991: 15). As reflexões apresentadas por Andrade e Silva (2017) quanto à autenticidade de materiais usados no ensino de línguas contribuem para enriquecer os critérios de seleção de textos a serem empregados para fins didáticos.

Quanto à formação de professores, entrou em vigor em 2008 uma nova estrutura curricular para a Licenciatura em Letras na USP, estabelecendo uma interface entre os Departamentos de Línguas e a Faculdade de Educação (SIMÕES 2015: 248-49). Simões (2015: 250-51) esclarece:

A disciplina de interface oferecida até o momento pela Área de Alemão é denominada FLM0640 - Aquisição-Aprendizagem de Alemão como Língua Estrangeira e tem como foco a discussão das principais teorias de aquisição, aprendizagem e ensino de língua alemã como língua estrangeira. Ministrada em língua alemã, a disciplina funciona como um insumo suplementar de língua para os formandos, que são confrontados com textos técnicos na língua alvo. O programa dessa disciplina promove o acesso a um panorama das teorias mais recentes de aquisição de línguas estrangeiras e de metodologia do ensino do alemão e sua aplicação prática através da análise de materiais didáticos de diferentes gerações.

Desse modo, surgiu no ano de 2009 a disciplina Aquisição/Aprendizagem do Alemão como Língua Estrangeira (UPHOFF \& PEREZ 2015: 19). Foi somente naquele ano que a formação de professores passou a ter maior destaque no currículo da USP, embora estivesse em vigor desde 2004 o Programa de Formação de Professores da USP que atendia à resolução do MEC de um modelo de interface entre as unidades de origem e a FEUSP para os cursos de licenciatura (SIMÕES 2015). O fato de a nova disciplina 
funcionar "como um insumo suplementar de língua para os formandos" (SIMÕES 2015: 250) reforça seu papel especial na formação em Letras/Alemão pela USP.

Em relação às línguas adicionais, o Projeto Pedagógico do Curso de Letras da USP (2013, s/p) passou finalmente a enfatizar que "um Curso de Letras é diferente de um curso de línguas estrangeiras", ao não visar, "exclusiva ou principalmente, à aquisição de proficiência em línguas estrangeiras", diante da ideia compartilhada por muitos graduandos de que um curso de Letras em que não há pré-requisito de conhecimento da língua é uma espécie de curso de línguas. Desse modo,

[...] [u]m curso de Letras é o lugar onde se aprende a refletir sobre os fatos linguísticos e literários, analisando-os, descrevendo-os e explicando-os. A análise, a descrição e a explicação do fato linguístico e literário não podem ser feitas de maneira empírica, mas devem pressupor reflexão crítica bem fundamentada teoricamente (PROJETO 2013: s/p).

Isto significa que as aulas de língua no curso de Letras consideram a língua não só como ferramenta de análise, mas também como objeto de análise; isto é, levam a reflexão acerca da língua ao nível metalinguístico.

Uma tentativa de contornar a percepção da graduação em Letras como curso de língua foi a criação do ciclo básico, destinado "a dar uma formação mais geral ao estudante": durante o primeiro ano da graduação em Letras, são cursadas disciplinas introdutórias nas áreas de Linguística, Estudos da Língua Portuguesa, Letras Clássicas e Teoria Literária. Segundo o Projeto, "[o] ciclo básico foi criado porque os alunos chegavam ao Curso de Letras concebendo-o como um curso de línguas e não como um curso que visa a compreender o funcionamento da linguagem humana”, e a experiência tem sido bem-sucedida (PROJETO 2013, s/p).

Para Blume (2011: 56), a visão dos alunos de que a graduação em Letras é uma espécie de curso gratuito de língua estrangeira é reforçada pelo fato de que "a grande carga de aulas de língua estrangeira tem sido ministrada historicamente como se fosse um curso de língua estrangeira qualquer”. O Projeto Pedagógico da USP afirma o seguinte em relação à ausência da necessidade de conhecimentos prévios na língua para cursar a habilitação:

No que diz respeito às Letras Estrangeiras Modernas, com exceção da língua inglesa, que pressupõe do ingressante um conhecimento prévio de grau intermediário, pois é uma das disciplinas constantes da grade curricular do ensino médio, as outras línguas começam a ser ministradas a partir de um nível elementar e, de acordo com as dificuldades específicas de cada uma delas, têm a tarefa de propiciar ao aluno conhecimentos de língua que the possibilitem desenvolver a capacidade de leitura, expressão escrita e oral. [...] Isso é feito 
GRILLI, M. - A abordagem CLIL na graduação em Letras/Alemão

sem deixar de lado o que é a especificidade de um curso superior de Letras: a reflexão sobre os fatos linguísticos e literários (PROJETO 2013, s/p).

Portanto, coloca-se como objetivo do curso o desenvolvimento da "capacidade de leitura, expressão escrita e oral"; da mesma forma, as disciplinas de língua alemã objetivam "capacitar o aluno nas quatro habilidades linguísticas" (PROJETO 2013, s/p). Também é considerada uma das habilidades específicas nas habilitações em Letras Estrangeiras Modernas o "domínio do uso da língua estrangeira moderna, nas suas modalidades oral e escrita, em termos de recepção e produção de textos”.

Além disso, o Projeto dedica todo um capítulo a justificar a realidade do Curso de Letras com base na realidade educacional brasileira, no qual afirma:

Como dissemos, essas habilidades [orais e escritas] deveriam ser pré-requisitos para ingressar num Curso de Letras. Não é, no entanto, o que ocorre com os nossos alunos, em função da maneira como se ensinam português e línguas estrangeiras (reduzidas praticamente ao ensino do inglês) no ensino fundamental e médio, conforme descrevemos em item anterior. $\mathrm{O}$ aluno chega ao curso superior sem ser capaz de usar, de maneira competente, a norma culta da Língua Portuguesa em sua modalidade escrita. No que tange às línguas estrangeiras, o aluno não consegue sequer ler, com proficiência, textos corriqueiros (PROJETO 2013, s/p).

Assim, é reafirmado o compromisso de aproximar-se cada vez mais do ideal, com o auxílio das "mais novas técnicas didáticas e metodológicas", aliando "a aquisição do que seriam os pré-requisitos para um curso superior e as habilidades que se esperam de um graduado em Letras" (PROJETO 2013, s/p).

\subsection{Os desafios relatados pelo graduado em Letras/Alemão}

A fim de complementar as reflexões suscitadas por pesquisas como a de Uphoff \& Debia (2017) e Voerkel (2017), que investigam a percepção de graduandos em Letras/Alemão acerca das dificuldades do curso, o estudo relatado a seguir trabalhou com as impressões dos alunos de uma disciplina de pós-graduação em Letras/Alemão sobre sua formação inicial. Durante uma aula cujo conteúdo era relativo ao currículo do curso, os seis alunos presentes concordaram em responder a um questionário com nove perguntas e, em seguida, debater suas respostas. O questionário continha questões dissertativas e questões no formato de escala.

$\mathrm{Na}$ primeira questão, o participante deveria assinalar as alternativas correspondentes ao curso de graduação que havia realizado: bacharelado ou licenciatura, com habilitação simples em Alemão ou habilitação dupla em Português e Alemão. Nas 
GRILLI, M. - A abordagem CLIL na graduação em Letras/Alemão

três questões seguintes, deveria especificar em qual universidade realizou esses cursos, seu ano de ingresso e de término.

As questões 5 e 6, reproduzidas na Figura 3, solicitavam que o aluno nomeasse as disciplinas que havia cursado durante a graduação e as classificasse quanto ao nível de dificuldade de cada uma. Esse procedimento, além de estimular a reflexão sobre o currículo, permitiria uma posterior comparação entre as grades curriculares.

Figura 3. Questões 5 e 6 do questionário para graduados em Letras/Alemão.

5. Quantas disciplinas da grade curricular do[s] curso[s] você consegue nomear sob cada bloco? a) Lingua Alemã
6. Qual foi $\circ$ seu $\circ$ nivel de dificuldade acompanhá-las?

[1 = muito fácil; 5 = muito dificil $]$

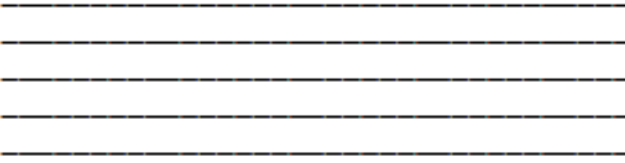

b) Literatura Alemã

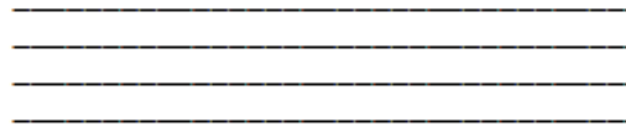

c) Linguística Alemã

d) Tradução do Alemão

e) Didática do Alemão

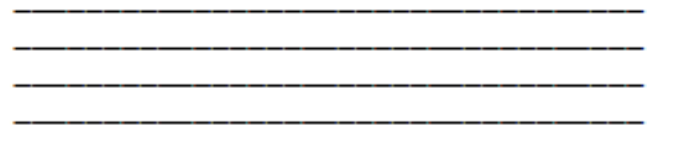

f) História e Cultura Alemã

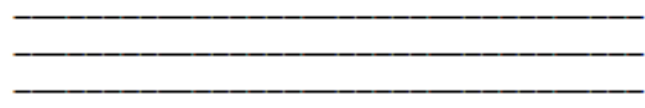

g) Estágio de Observação

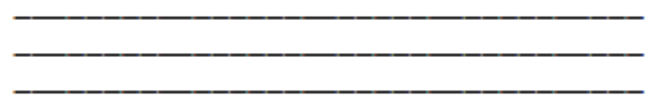

h) Estágio de Regência

não cursei não cursei não cursei não cursei não cursei

não cursei não cursei não cursei não cursei

não cursei não cursei não cursei

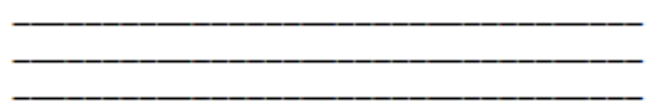

$\begin{array}{llllll}1 & 2 & 3 & 4 & 5 & \text { não cursei } \\ 1 & 2 & 3 & 4 & 5 & \text { não cursei } \\ 1 & 2 & 3 & 4 & 5 & \text { não cursei }\end{array}$

Fonte: elaboração própria 
GRILLI, M. - A abordagem CLIL na graduação em Letras/Alemão

No verso da folha, as questões dissertativas 7, 8 e 9 interrogavam sobre as causas das dificuldades em acompanhar algumas disciplinas, pediam sugestões para melhorias no currículo e abriam espaço para outros comentários.

Dos seis alunos que responderam ao questionário, dois haviam cursado a Licenciatura em Letras no IFPLA e não na USP. Trata-se da única graduação em Letras/Alemão do país em que é exigida uma proficiência mínima em alemão de nível B1 para ingressar no curso, isto é, as aulas de língua alemã não têm início do nível básico. Mesmo assim, esses dois participantes relataram ter cursado quatro disciplinas de língua, de nível de dificuldade 2. Além disso, cursaram duas ou três de literatura, cujos níveis de dificuldade variaram entre 2 e 4 , e uma disciplina de cultura alemã, para a qual apontaram nível 2 e nível 4 de dificuldade. Não houve disciplinas de linguística nem de tradução no currículo, mas os estágios de observação e de regência, em língua alemã e em língua portuguesa, totalizaram oito, de nível de dificuldade 2.

Como causas das dificuldades, ambos citaram os temas previamente desconhecidos trabalhados nas disciplinas, e como sugestões para a melhoria do currículo, cursos extras de língua em nível avançado. Um deles comentou ter observado "encontros para compartilhar conhecimentos" em alemão na USP, citando como exemplo o Deutscher Filmklub; trata-se de um projeto idealizado e administrado por alunos, em que é transmitido e discutido um filme falado originalmente ou dublado em alemão, também com legendas em alemão, a cada dois sábados.

Dentre os quatro alunos que haviam cursado Letras/Alemão na USP, um deles havia concluído o bacharelado quando da aplicação deste questionário, mas ainda cursava a licenciatura. As disciplinas apontadas pelos participantes e o grau de dificuldade de cada uma delas estão representados na Tabela 1, à direita das letras que identificam os informantes e do período em que cursaram Letras/Alemão.

$\mathrm{O}$ algarismo representa a quantidade de disciplinas que o participante nomeou sob cada bloco, e o tamanho do algarismo representa o nível de dificuldade desse bloco de disciplinas, de 1 a 5, conforme a escala:

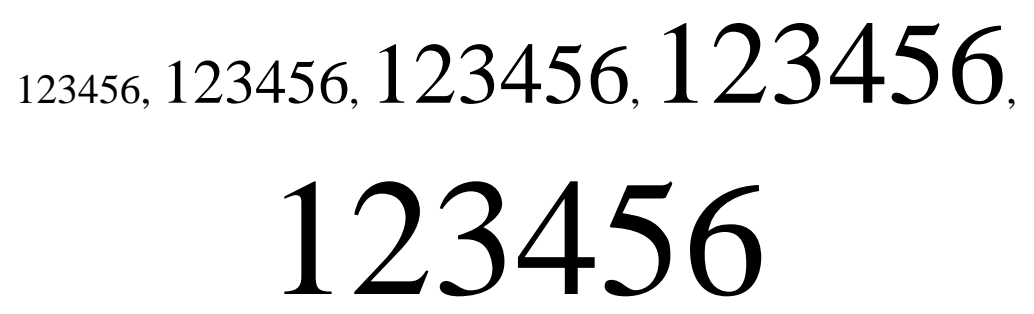

Pandaemonium, São Paulo, v. 25, n. 46, mai.-ago. 2022, p. 172-201 
GRILLI, M. - A abordagem CLIL na graduação em Letras/Alemão

No caso de serem citadas mais de uma disciplina sob cada bloco, foi inserida na tabela a média dos níveis de dificuldade apontados, arredondando-se para cima quando necessário. Por exemplo, o participante B selecionou progressivamente os níveis de dificuldade 2, 3 e 4 para cada duas das seis disciplinas de língua que cursou, e a marca inserida na tabela corresponde ao nível 3. Já o participante D atribuiu os níveis de dificuldade 2, 4 e 4 para as três disciplinas de literatura, respectivamente, e para a tabela foi considerada a dificuldade correspondente ao nível 4.

Somente um participante nomeou uma disciplina que não havia cursado, à exceção do estágio de regência de aula, que constava dos subtópicos do questionário mas foi realizado por apenas um dos participantes.

Tabela 1. Disciplinas cursadas por graduados em Letras/Alemão na USP e seus níveis de dificuldade.

\begin{tabular}{|c|c|c|c|c|c|c|c|c|}
\hline \multicolumn{9}{|c|}{ Disciplinas cursadas e seus níveis de dificuldade } \\
\hline & Língua & $\begin{array}{c}\text { Linguís- } \\
\text { tica }\end{array}$ & Literatura & Tradução & Cultura & Didática & $\begin{array}{l}\text { Obser- } \\
\text { vação }\end{array}$ & Regência \\
\hline $\begin{array}{c}\mathbf{A} \\
2002- \\
2006\end{array}$ & 6 & 2 & 1 & 2 & & 1 & 1 & 1 \\
\hline $\begin{array}{c}\mathbf{B} \\
2007- \\
2013\end{array}$ & 6 & 2 & & 2 & 1 & 3 & 1 & \\
\hline $\begin{array}{c}\text { C } \\
2009- \\
2013\end{array}$ & 5 & 1 & & 3 & 2 & 1 & 1 & \\
\hline $\begin{array}{c}\mathbf{D} \\
2009- \\
2015\end{array}$ & 4 & 2 & 4 & 1 & 2 & 1 & 1 & \\
\hline
\end{tabular}

Fonte: elaboração própria

Desse modo, percebemos que a maior quantidade de disciplinas oferecidas no currículo é de língua alemã, mesmo considerando possíveis falhas de memória ou diferenças entre as grades curriculares cursadas por cada participante. 
GRILLI, M. - A abordagem CLIL na graduação em Letras/Alemão

As disciplinas de tradução são mais diversificadas e mais exigentes do que as de linguística, tendo inclusive o participante D nomeado duas disciplinas de tradução, embora tivesse cursado apenas uma. No entanto, as disciplinas de literatura alemã definitivamente ultrapassam em diversificação e nível de dificuldade as de linguística e de tradução.

As disciplinas relacionadas à cultura dos países de língua alemã também não foram consideradas fáceis, de modo geral, por nenhum dos participantes. Vale ressaltar que alguns deles consideraram a disciplina História da Literatura Alemã como parte do bloco de cultura, e outros, do bloco de literatura; assim, além desta, teria sido apontada uma única disciplina de cultura alemã por cada participante.

Os participantes B e D chegaram a cursar Aquisição/Aprendizagem, e atribuíram à disciplina um nível de dificuldade maior do que o de Metodologia do Ensino de Alemão como Língua Estrangeira, disciplina obrigatória oferecida na Faculdade de Educação e ministrada exclusivamente em língua portuguesa.

Desse modo, não parece haver diferenças relevantes entre as impressões sobre o curso do participante que concluiu o curso em 2006, por aquele que passou pela reforma curricular de 2009 e pelos que já ingressaram na graduação após essa reforma. Tanto na opinião de ex-alunos mais antigos quanto dos mais recentes, as disciplinas de literatura seguramente têm maior peso na graduação em Letras/Alemão da USP do que as de linguística e tradução, o que confirma o foco no ensino de língua e de literatura, sustentado pelo Projeto Pedagógico do Curso de Letras da USP atualizado em 2013 (Cf. item 2.2.2).

Em comparação com a grade curricular do IFPLA, segundo os dois participantes lá graduados, os estágios de observação e de regência da USP são menos extensos e menos exigentes: esses dois participantes realizaram dois estágios em língua alemã e dois em língua portuguesa em cada bloco, de nível médio de dificuldade 2. A comparação sugere que a formação em didática de LE oferecida na licenciatura da USP poderia ser mais completa - sem esquecer, porém, que as duas instituições se inserem em contextos muito diferentes e trabalham a intersecção entre língua e conteúdo de formas distintas.

Pode-se observar ainda que o nível médio de dificuldade atribuído às disciplinas de língua não é alto, enquanto as de literatura foram consideradas as mais difíceis. Por outro lado, o convívio com alunos de graduação mostra que comentários sobre a dificuldade de acompanhá-las são bastante recorrentes - seja devido às periódicas 
GRILLI, M. - A abordagem CLIL na graduação em Letras/Alemão

mudanças no material didático utilizado nas aulas de língua, seja devido à comparação com as disciplinas posteriores que pressupõem certo conhecimento da língua.

O fato é que a brusca "passagem" das aulas de língua para as de literatura não parece ter sofrido impacto significativo na USP com a reforma de 2009. Parecem concordar com esse fato os participantes do estudo relatado por Uphoff \& Debia (2017), em cujas considerações finais constam como sugestões "um uso mais seletivo do livro didático" e "o trabalho com mais textos autênticos, especialmente literários" (UPHOFF \& DeBIA, 2017: 187). Nesse sentido, o estudo de Barcellos (2017) aponta resultados positivos com a introdução de literatura alemã contemporânea nas disciplinas de língua do curso de Letras da UNESP-Araraquara.

Entretanto, um estudo realizado por Voerkel (2017: 310-311) demonstrou que dois terços dos graduandos brasileiros atingem o nível de proficiência B2 ou superior ao fim do curso de Letras/Alemão - ainda que esse número seja muito menor ao fim das disciplinas de língua propriamente ditas. Desse modo, uma solução viável para as dificuldades linguísticas encontradas por graduandos em Letras/Alemão pode estar em olhar para além dessa dicotomia língua versus literatura e ampliar as perspectivas sobre outras dimensões da grade curricular.

Ao invés de considerar as aulas de língua como um meio, e as de literatura, um fim, será mais proveitoso adotar a perspectiva de que todas as disciplinas - língua, literatura, linguística, tradução, cultura e didática - são um meio para atingir o mesmo fim: o desenvolvimento da "capacidade de leitura, expressão escrita e oral", "nas quatro habilidades linguísticas" (PROJETO 2013, s/p), além de todas as outras contribuições que a graduação em Letras pretende abordar para a formação dos futuros profissionais.

Outro estudo realizado com graduandos em Letras/Alemão, desta vez em uma universidade pública do Paraná, apontou que a realização de um intercâmbio seria "uma forma eficaz de os alunos atingirem um nível de proficiência válido da língua e conhecer a cultura do país alvo, duas competências essenciais, principalmente na hora de optar pela carreira docente" (GARCÍA et al. 2017: 54).

É aí que reside o potencial do CLIL enquanto recurso pedagógico na graduação: ao transformar o bilinguismo em um meio, ao invés de um fim, é possível conseguir uma progressão equilibrada do conhecimento de língua e de conteúdo dos graduandos em maior escala. Essa perspectiva estaria de acordo com a defesa de uma postura heteroglóssica no ensino bilíngue (GARCÍA 2009), ao validar o plurilinguismo e a 
GRILLI, M. - A abordagem CLIL na graduação em Letras/Alemão

multimodalidade intrínseca ao ato comunicativo nas atividades discentes. Assim, os aprendizes brasileiros de alemão deixam de depender da realização de um intercâmbio para alcançar a autonomia no uso da língua, o que representa maior igualdade de oportunidades para aqueles que não podem custear nem mesmo parte de uma viagem à Europa. Na próxima seção, veremos algumas sugestões de como alcançar esse objetivo.

\section{Unindo a teoria do CLIL à prática na universidade}

Teoricamente, qualquer disciplina da grade curricular de Letras/Alemão poderia se configurar como curso CLIL, ao tratar-se do ensino bilíngue de um conteúdo específico, na qual a língua alemã é também objeto de ensino-aprendizagem. Dentre as variantes do CLIL em alemão definidas por Haataja \& Wicke (2016), as disciplinas de um curso de Letras podem ser classificadas como bilingualer Sachfachunterricht mit Deutsch als Zielsprache e como fächerübergreifender Deutsch als Fremdsprache-Unterricht - isto é, enquadram-se como aulas bilíngues que têm o alemão como língua-alvo e aulas de língua que abrangem conteúdo disciplinar.

Essas denominações se referem às práticas dos professores que intercalam ambas as línguas durante a aula, buscando facilitar o caminho dos alunos até o objetivo de apropriarem-se de conhecimentos acerca da literatura alemã. Pode-se categorizar essas disciplinas de literatura nas universidades brasileiras como pertencentes à variante bilingualer Sachfachunterricht mit Deutsch als Zielsprache, isto é, aula bilíngue que tem o alemão como língua-alvo.

Já as disciplinas em que a L1 é apenas permitida, e não usada pelo professor durante a exposição do conteúdo, consistem em imersão estruturada na língua alemã, conforme a descrição desse tipo de programa já comentada na seção 1.1: o ensino em si não é bilíngue, e sim, aproxima os alunos do bilinguismo por meio de um intenso contato com o alemão. Além disso, existe a oferta de suporte acadêmico para os alunos, na medida em que são sugeridos textos de aprofundamento teórico na L1 e traduções das obras estudadas.

Entretanto, cabe questionar se esse é o melhor modelo. Afinal, a legislação concernente ao ensino básico já determinou que no máximo $50 \%$ da grade curricular pode ser ministrada na língua adicional - e a carga horária de aulas nas escolas bilíngues, geralmente colégios privados, é superior àquela praticada no ensino superior. A exceção

Pandaemonium, São Paulo, v. 25, n. 46, mai.-ago. 2022, p. 172-201 
GRILLI, M. - A abordagem CLIL na graduação em Letras/Alemão

são os cursos de graduação em período integral, que não costuma ser o caso de Letras. Além disso, sabe-se que crianças e adolescentes tendem a aprender mais rápido do que adultos.

Por que, então, expor aprendizes adultos, das mais variadas idades e históricos educacionais, a aulas integralmente na língua adicional? Será este o melhor caminho para que eles desenvolvam competências análogas àquelas definidas no Projeto Pedagógico da USP (2013)? Ou será que ainda estamos reproduzindo os paradigmas do bilinguismo transicional, calcados numa pretensa superioridade da língua-alvo?

\subsection{Por um ensino verdadeiramente bilíngue na graduação}

Os participantes do estudo relatado acima, bem como de outros estudos publicados anteriormente (UPHOFF \& DEBIA, 2017, GARCíA et al. 2017), enfatizam sua dificuldade nas disciplinas de conteúdo durante a graduação. Portanto, parece ser consenso a necessidade de revisar a polarização entre língua e conteúdo nos currículos de Letras/Alemão. Além disso, o que geralmente se entende por conteúdo em cursos de Letras é a literatura relacionada à língua sendo estudada, "negligenciando as múltiplas outras formas de expressão cultural literária ou não-literária”:

[...] apesar das muitas formas, usos, usuários e contextos de língua e cultura, uma forma de língua e um tipo de texto, nomeadamente a linguagem de textos especificamente literários, detém um comando tão extenso sobre os objetivos do currículo de $\mathrm{ALE}^{5}$ (PLEWS, 2007: 13 apud SCHMENK 2010: 36).

Segundo Schmenk (2010: 38), tanto as disciplinas de literatura ministradas exclusivamente em língua alemã quanto as disciplinas adicionais como cinema ou estudos culturais, oferecidas em língua materna, reforçam a divisão entre língua e conteúdo, não proporcionando ao aluno uma integração entre as línguas e culturas. O fato de as disciplinas de conteúdo não-literário serem, muitas vezes, ministradas na língua materna dos alunos, denota que não lhes é conferida a mesma importância dada aos estudos literários.

É interessante notar que os autores supracitados Barbara Schmenk e John Plews se referem ao ensino universitário de alemão no Canadá, com críticas que se aplicam com precisão à realidade brasileira. Já na Turquia, Genç, Ünal \& Ünver (2018) propuseram a

\footnotetext{
${ }^{5}$ No original, " $[\ldots]$ despite the many forms, uses, users, and contexts of language and culture, one form of language and one kind of text, namely the language of specifically literary texts, holds such an extensive command over the goals of the GFL curriculum". Tradução nossa.
} 
GRILLI, M. - A abordagem CLIL na graduação em Letras/Alemão

elaboração de um material didático para o curso de licenciatura em Letras/Alemão, a ser empregado nas aulas de conteúdo, que têm início após dois semestres com foco na língua.

A oferta de disciplinas de cultura e mesmo de literatura em língua materna, como alternativa encontrada em ambos os países para suprir a lacuna no conhecimento de língua, ocorre também na Alemanha: segundo Rösler (2010: 12), o currículo é dividido entre as aulas de língua, que deveriam interagir mais com as disciplinas de conteúdo, e as aulas de conteúdo, que deveriam ser percebidas como parte da aprendizagem de língua. No entanto, o melhor seria questionar o que poderia ser feito para combinar ambos, no sentido de desenvolver a competência linguística e proporcionar um desafio intelectual. O autor sugere:

[...] deve-se, ao mesmo tempo, traçar um limite entre aulas de língua e aulas de conteúdo e atenuar esse limite, sabendo que práticas de ensino e sessões de formação de professores colaborativas precisam ser construídas e fomentadas, para atender às mais complexas demandas de um mundo mais multilíngue, no qual professores de língua e de conteúdo juntos têm um papel essencial na promoção e na explicação do mundo multilíngue (RÖSLER 2010: 15). ${ }^{6}$

Genç, Ünal \& Ünver (2018: 259-260) afirmam que falta uma didática específica para Fachsprache na universidade. Para Uphoff \& Debia (2017: 181), a estratégia mais viável é estender o trabalho nas aulas de língua não só aos textos literários, mas também a outros gêneros de textos autênticos e à prática da escrita acadêmica, em oposição ao que ocorre em "um curso de idiomas com foco comunicativo" (UPHOFF \& DEBIA 2017: 176).

A distribuição mais homogênea de uma maior variedade de gêneros textuais ao longo de todas as disciplinas do curso de Letras poderia representar uma autonomia dos cursos brasileiros, levando, consequentemente, à autonomia dos futuros profissionais da área em relação ao uso da língua para diferentes finalidades. Em última análise, essa postura tem o potencial de representar uma superação do paradigma colonial que nos tem levado a desvalorizar sistematicamente a língua materna de aprendizes e de professores brasileiros de alemão - e a crer que a única maneira de aprender efetivamente a língua alemã é realizar um intercâmbio.

\footnotetext{
${ }^{6}$ No original, "[...] one has to both draw a line and blur that line between language classes and content classes, knowing that collaborative teaching practices and teachers' training sessions have to be built and supported to meet the more complex demands of a more multilingual world in which language and content teachers together have a key role for promoting and explaining the multilingual world". Tradução nossa.
} 
GRILLI, M. - A abordagem CLIL na graduação em Letras/Alemão

\subsection{As dimensões CLIL na universidade}

Se pensarmos nos oito blocos gerais de disciplinas listados no questionário integrante do estudo relatado na seção 3.2.3, conforme mostrado na Figura 3, é fácil relacioná-las às cinco dimensões do CLIL:

- cultura: Literatura Alemã, História e Cultura Alemã

- ambiente: História e Cultura Alemã

- língua: Língua Alemã, Linguística Alemã, Tradução do Alemão

- conteúdo: Literatura Alemã

- aprendizagem: Tradução do Alemão, Didática do Alemão, Estágio de Observação, Estágio de Regência

Mesmo que essas correlações sejam aproximadas, elas servem para despertar a consciência de docentes e graduandos para as possibilidades de trabalho com o CLIL já existentes nos currículos brasileiros de graduação em Letras/Alemão.

A reflexão fica mais complexa ao considerarmos os seis verbos-chave dos níveis de aprendizagem conforme a Taxonomia de Bloom, a fim de buscar indícios de todos os níveis na progressão da língua e do conteúdo nesses currículos. Segundo o trecho mencionado anteriormente do Projeto Pedagógico do Curso de Letras da USP (2013, s/p), o objetivo de um curso de Letras é aprender a analisar, descrever e explicar fatos linguísticos e literários. Isso significa que o graduando é levado com segurança até o quarto dos seis níveis da taxonomia: além de descrever e explicar fatos linguísticos e literários, habilidades correspondentes aos dois primeiros níveis, ele também os analisa isto é, propõe conexões originais entre os fatos, comparando-os e contrastando-os.

A escrita de trabalhos acadêmicos representa uma parte significativa das atividades realizadas no âmbito de um curso de Letras e um espaço para a aplicação de HOTS, por meio da análise de obras escolhidas pelo aluno conforme aspectos teóricos também escolhidos pelo aluno. Porém, o quinto nível da taxonomia, que corresponde à habilidade de avaliar e de tomar decisões, e o sexto nível, relativo à criação de trabalhos originais, não são explicitados como objetivos do curso de graduação em Letras da USP.

Portanto, sem esquecermos de que a USP é apenas uma universidade dentre as 17 que oferecem a graduação em Letras/Alemão no Brasil, observa-se o seguinte: embora seja objetivo definido no Projeto Pedagógico o domínio da língua adicional em todas as 
GRILLI, M. - A abordagem CLIL na graduação em Letras/Alemão

suas competências, as competências superiores da taxonomia de Bloom não integram explicitamente o Projeto.

Quanto às especificidades da licenciatura, a já mencionada Resolução CNP/CP que institui diretrizes para a formação docente para a Educação Básica (BRASIL 2002a) estabelece em seu artigo $3^{\circ}$, parágrafo III, que essa formação deve considerar

[...] a pesquisa, com foco no processo de ensino e de aprendizagem, uma vez que ensinar requer, tanto dispor de conhecimentos e mobilizá-los para a ação, como compreender o processo de construção do conhecimento.

Ora, o ato de pesquisar envolve necessariamente a análise e a avaliação, duas das habilidades de pensamento de ordem superior que aparecem na taxonomia de Bloom. Para que exista no curso de Letras/Alemão um espaço consolidado como CLIL, basta acrescentar oportunidades para os aprendizes criarem suas próprias representações da realidade conforme a apreendem.

Para tanto, é necessário reinterpretar a função que as disciplinas do curso desempenham na formação desses aprendizes. Nessa perspectiva, a língua deixa de ser percebida como um sistema de regras e ganha vida nos discursos autênticos dos aprendizes, que constituem e são constituídos por seus repertórios espaciais ${ }^{7}$, com base nas ideologias que permeiam sua visão de mundo.

Recusar a hierarquização das línguas passa por reconhecer que a língua se constitui por meio de práticas sociais, e que cada falante constrói socialmente seus próprios repertórios espaciais, isto é, seus repertórios linguísticos em correlação com os meios em que os mobiliza (PENNYCOOK \& OTSUJ 2014). A língua alemã, assim, expande, e não restringe as possibilidades de expressão criativa de quem aprende.

Os estudos culturais e da tradução, por meio da postura de interculturalidade crítica que vem ganhando espaço nas discussões em Educação Linguística (Cf. CANDAU 2008), trazem o potencial de desvelar as representações que o outro faz de si mesmo e do próprio mundo, conferindo recursos para que os aprendizes construam as próprias representações de maneira horizontal e não submissa àquelas que vêm da Europa.

Já as temidas disciplinas de literatura funcionam perfeitamente como provedoras de uma ampla gama de modelos de representações da realidade, conferindo aos

\footnotetext{
${ }^{7}$ Para uma compreensão aprofundada dos conceitos de língua como sistema, discurso e ideologia, cf. Kumaravadivelu (2006).

Pandaemonium, São Paulo, v. 25, n. 46, mai.-ago. 2022, p. 172-201
} 
GRILLI, M. - A abordagem CLIL na graduação em Letras/Alemão

aprendizes recursos para criarem suas próprias obras curtas, segundo determinado estilo ou escola literária.

Por fim, o bloco de disciplinas relativas à aprendizagem abre espaço para que os futuros professores criem suas próprias representações significativas ao prover-lhes estratégias para uma prática docente autoral, calcada nos parâmetros e nas estratégias pósmétodo (cf. KuMARAVADIVElu 2006), ao invés de treiná-los para aplicar de maneira acrítica manuais de ensino vindos da Europa, concebidos sem qualquer contato com a realidade em que atuarão esses futuros professores.

\section{Conclusão}

Antes da consolidação da abordagem CLIL, acreditava-se que os recursos linguísticodiscursivos da língua-alvo não seriam suficientes para que o aprendiz conseguisse lidar com conteúdos disciplinares de crescente complexidade (VOLLMER 2010: 124). Além disso, ainda existem defensores da ideia de que a aula de conteúdo em outra língua impede a apreensão desse conteúdo (SCHMELTER 2013: 42).

Essas críticas só provam o quanto o ensino bilíngue de fato, e não monolíngue na língua-alvo, foge à regra de modelos conhecidos de ensino e ainda não está muito bem consolidado em determinados contextos, pois se referem a espaços supostamente bilíngues, mas construídos de forma monoglóssica, "uma vez que reforçam práticas de compartimentalização das línguas separadas rigidamente por horários, salas, professores ou disciplinas" (LIBERALI 2020: 81).

Assim, devido à tradicional cisão entre as disciplinas obrigatórias de língua e de literatura, grande parte do curso de Letras/Alemão na USP gira em torno das disciplinas de literatura, que são temidas por aqueles que ainda as cursarão, e lembradas como muito difíceis por aqueles que já passaram por elas.

Com base no histórico dos currículos de graduação em Letras/Alemão, sobretudo do currículo vigente na USP, bem como nas percepções dos alunos egressos desses currículos, é possível concluir que a abordagem CLIL apresenta o potencial de constituir espaços de ensino-aprendizagem efetivamente bilíngues. Pensar na grade do curso como composta pelas cinco dimensões CLIL pode auxiliar na compreensão de como essas disciplinas estão integradas entre si, conferindo um caráter mais horizontal à percepção de alunos e docentes acerca de toda a grade curricular.

Pandaemonium, São Paulo, v. 25, n. 46, mai.-ago. 2022, p. 172-201 
GRILLI, M. - A abordagem CLIL na graduação em Letras/Alemão

Além disso, elaborar a ementa das disciplinas levando também em consideração a taxonomia de Bloom pode contribuir para o processo de levar os aprendizes a transcender as habilidades de pensamento de ordem inferior, cujo foco é memorizar e aplicar conceitos, em direção a um engajamento em representações criativas significativas. Desse modo, tanto a língua quanto o conteúdo serão efetivamente aprendidos.

Na dissertação de mestrado que deu origem a este artigo, afirmou-se que uma disciplina nos moldes CLIL no currículo de Letras/Alemão apresentaria grande potencial para mediar a passagem entre as aulas de língua e as de literatura. Aqui, essa afirmação dá lugar a outra mais ampla: assumir uma perspectiva CLIL integral nos cursos de Letras/Alemão brasileiros tem muito a agregar na formação de profissionais capazes de fazer uso da língua e da literatura, e também da tradução e da didática, conforme lhes pareça apropriado - com ou sem intercâmbio.

\section{Referências bibliográficas}

ANDERSON, Lorin W.; KRATHWOHL, David R. A Taxonomy for Learning, Teaching, and Assessing. A Revision of Bloom's Taxonomy of Educational Objectives. New York et al.: Longman, 2001.

Andrade E SiLva, Mariana Kuntz de. Autenticidade de materiais e ensino de línguas estrangeiras. Pandaemonium Germanicum, v. 20, n. 31, 1-29, 2017.

BARCELLOS, Natália Corrêa Porto Fadel. Aprender a língua por meio da literatura no contexto da Germanística brasileira: uma experiência realizada na UNESP-Araraquara. In: UPHOOF, Dörthe et al. (Orgs.). O Ensino de Alemão em contexto universitário: modalidades, desafios e perspectivas. São Paulo: Humanitas, 2017, 191-210.

Bloom, Benjamin S. (Org.). Taxonomy of educational objectives. Volume 1: Cognitive domain. New York: David McKay, 1956.

Blume, Rosvitha Friesen. Prática como Componente Curricular - Desafio e oportunidade na formação universitária de professores de alemão no Brasil. In: BOHUNOVSKY, R. (Org.). Ensinar alemão no Brasil: contextos e conteúdos. Curitiba: Editora UFPR, 2011, 53-68.

BRASIL. Lei $n^{\circ}$ 9.394, de 20 de dezembro de 1996. Estabelece as diretrizes e bases da educação nacional. Brasília, $1996 . \quad$ DF: http://www.planalto.gov.br/ccivil_03/LEIS/L9394.htm. (20/05/ 2021).

BRASIL. Parecer CNE/CP 9/2001. Diretrizes Curriculares Nacionais para a Formação de Professores da Educação Básica, em nível superior, curso de licenciatura, de graduação plena. Disponível em: http://portal.mec.gov.br/cne/arquivos/pdf/009.pdf. (21/08/2021).

BRASIL. Parecer CNE/ CEB 2/2020. Diretrizes Curriculares Nacionais para a oferta de Educação Plurilíngue. Aguardando homologação. Disponível em: http://portal.mec.gov.br/docman/setembro-2020-pdf/156861-pceb002-20/file. (10/072021).

BRASIL. Resolução CNE/CP 1, de 18 de fevereiro de 2002a. Institui Diretrizes Curriculares Nacionais para a Formação de Professores da Educação Básica, em nível superior, curso

Pandaemonium, São Paulo, v. 25, n. 46, mai.-ago. 2022, p. 172-201 
GRILLI, M. - A abordagem CLIL na graduação em Letras/Alemão

de licenciatura, de graduação plena. Disponível em: http://portal.mec.gov.br/cne/arquivos/pdf/CP012002.pdf. (13/05/2021).

BRASIL. Resolução $C N E / C P$ 2, de 19 de fevereiro de 2002b. Institui a duração e a carga horária dos cursos de licenciatura, de graduação plena, de formação de professores da Educação Básica em nível superior. Disponível em: http://portal.mec.gov.br/docman/outubro-2020pdf/159251-rcp002-02/file. (13/05/2021).

BREIDBACH, Stephan. Geschichte und Entstehung des Bilingualen Unterrichts in Deutschland: Bilingualer Unterricht und Gesellschaftspolitik. In: HALLET, Wolfgang; KÖNIGS, Frank G. Handbuch Bilingualer Unterricht. Content and Language Integrated Learning. Seelze: Kallmeyer-Klett, 2013, 11-17.

CANDAU, Vera Maria. Direitos humanos, educação e interculturalidade: as tensões entre igualdade e diferença. Revista Brasileira de Educação, v. 13, n. 37, 45-56, 2008.

EURYDICE. Content and Language Integrated Learning (CLIL) at school in Europe. Brussels: Eurydice European Unit, 2006.

FRITZEN, Maristela P.; EWALD, Luana. "Aqui somos protegidos pelas nossas quatro paredes. Aqui nós falamos alemão": Histórias de letramentos interculturais no Vale do Itajaí, SC. In: Trab. Ling. Aplic., v. 52, n. 2, 239-258, 2013.

FRITZEN, Maristela P. Ich spreche anders, aber das ist auch Deutsch: línguas em conflito numa escola rural localizada em zona de imigração no sul do Brasil. In: Trab. Ling. Aplic., v. 47, n. 2 , 341-356, 2008.

GARCíA, André L. M.; Redel, Elisângela; MARTINY, Franciele M.; Voerkel, Paul. Crenças dos estudantes de Letras Português/Alemão: desafios, perspectivas e oportunidades. Pandaemonium Germanicum, v. 20, n. 31, 30-59, 2017.

GARCÍA, Ofélia. Bilingual Education in the 21st Century: a Global Perspective. Oxford: Blackwell Publishing, 2009.

GENÇ, Nurcihan S.; ÜNAL, D. Çiğdem; ÜNVER, Şerife. Entwicklung und Evaluation von fachund sprachintegrierten Unterrichtsmaterialien für die DaF-Lehrerausbildung in der Türkei. In: HAATAJA, Kim; WICKE, Rainer E. Fach- und sprachintegriertes Lernen auf Deutsch (CLILiG). Materialentwicklung, Lehrerbildung, Forschungsbegleitung. Berlim: Erich Schmidt Verlag, 2018, 259-267.

GRILLI, Marina. A abordagem CLIL na universidade e o desenvolvimento da leitura na graduação em Letras/Alemão. Dissertação (Mestrado em Letras) Faculdade de Filosofia, Letras e Ciências Humanas, Universidade de São Paulo. São Paulo, 2018.

GRILLI, Marina. CLIL em alemão no Brasil e a competência de leitura dos graduandos em Letras/Alemão. Pandaemonium Germanicum, v. 22, n. 38, 48-74, 2019.

GRILLI, Marina. Por que usar a LM na aula de LE: do plurilinguismo ao translinguismo. Revista Linguagem em Foco, v. 12, n. 3, 30-49, 2020.

HAATAJA, Kim; WiCKE, Rainer E. Fach- und Sprach- Integriertes Lernen in der Zielsprache Deutsch (CLILiG). Fremdsprache Deutsch, v. 27 n. 54 , 3-9, 2016.

HaAtaja, Kim; WICKE, Rainer E. Sprache und Fach. Integriertes Lernen in der Zielsprache Deutsch. München: Hueber, 2015.

HALL, Joan K. Methods for Teaching Foreign Languages. Creating a Community of Learners in the Classroom. Pearson, 2002.

HANESOVÁ, Dana. Development of Critical and Creative Thinking Skills in CLIL. Journal of Language and Cultural Education, v. 2, n. 2, 33-51, 2014.

KRAMSCH, Claire. Teaching foreign languages in an era of globalization: Introduction. The Modern Language Journal, v. 98, n. 1, 296-311, 2014.

KumARAVADIVELU, Bala. Understanding language teaching. From method to postmethod. New York: Routledge, 2006.

Pandaemonium, São Paulo, v. 25, n. 46, mai.-ago. 2022, p. 172-201 
GRILLI, M. - A abordagem CLIL na graduação em Letras/Alemão

LiBERALI, Fernanda. O desenvolvimento de agência e a Educação Multi/Bilíngue. In: MEgALE, Antonieta (Org.). Desafios e práticas na Educação Bilíngue. Vol. 2. São Paulo: Fundação Santillana, 2020, 79-91.

MARSH, David. Language Awareness and CLIL. In: CENOZ, Jasone; HoRNBERGER, Nancy H. Hornberger (Eds). Encyclopedia of Language and Education. Volume 6: Knowledge about Language. New York: Springer, 2008, 233-246.

Marsh, David; MALJERS, Anne; HARTIAla, Aini-Kristiina. Profiling European CLIL Classrooms. University of Jyväskylä, Finland and European Platform for Dutch Education, 2001.

Megale, Antonieta. Saberes necessários para a docência em escolas bilíngues no Brasil. In: Megale, Antonieta (Org.). Desafios e práticas na Educação Bilíngue. Vol. 2. São Paulo: Fundação Santillana, 2020, 15-26.

Megale, Antonieta; Liberali, Fernanda. Caminhos da Educação Bilíngue no Brasil: Perspectivas da Linguística Aplicada. Raído, v.10, n. 23, 9-24, 2016.

Mello, Heloísa A. B. Educação bilíngue: uma breve discussão. In: Horizontes de Linguística Aplicada, v. 9, n. 1, 118-140, 2010.

Mignolo, Walter. The Darker Side of Western Modernity. Durham/London: Duke University Press, 2011.

Negueruela-AZARola, Eduardo. Metáforas de la mente y enseñanza de idiomas: principios básicos para un enfoque conceptual basado en la teoría sociocultural de la mente humana. In: Justel, Joaquín Sueiro; Alonso, Miguel Cuevas; CEA, Vanessa Dacosta; PÉreZ, María Rosa (Orgs.). Linguística e Hispanismo. Lugo: Axac, 2010.

Neuner, Gerhard; Hufeisen, Britta; KuRsisa, Anta; MARX, Nicole; KoITHAn, Ute; ERLENWEIN, Sabine. Deutsch als zweite Fremdsprache. Berlin/München/Wien/Zürich/New York: Langenscheidt, 2009.

Nomura, Masa. O ensino de língua e literaturas estrangeiras. In: II Encontro de Professores de Línguas Estrangeiras. Assis, 1991, 14-19.

PaIVA, Vera Lúcia de Menezes de Oliveira. O novo perfil dos cursos de licenciatura em Letras. In: TOMITCH, Leda Maria Braga; VIEIRA-ABRAHÃO, Maria Helena.; DAGHLIAN, Carlos; RISTOFF, Dilvo I. (ORGS.). A interculturalidade no ensino de inglês. Florianópolis: UFSC, 2005, 345-363. (Advanced Research English Series). Disponível em: http://www.veramenezes.com/perfil.htm. (20/08/2021).

PENNYCOOK, Alastair; OTSUJI, Emi. Metrolingual multitasking and spatial repertoires: 'Pizza mo two minutes coming. Journal of Sociolinguistics, v. 18, n. 2, 161-184, 2014.

PLEWS, John L. The core, the outside and the borders: A critical curriculum history of postsecondary German in Canada. In: RIEGER, C L.; PLEWS, John L.; LOREY, Christoph (Orgs.). Interkulturelle Kompetenzen im Fremdpsrachenunterricht. Intercultural literacies and German in the classroom. Festschrift für Manfred Prokop zum 65. Geburtstag. Tübingen: Narr, 2007, 1-27.

Projeto Pedagógico do CuRso de Letras. São Paulo: FFLCH/USP, 2013.

PUPP SPINASSÉ, Karen. As interferências da Língua Materna e o aprendizado do Alemão como Língua Estrangeira por crianças bilíngues. In: Pandaemonium Germanicum, v. 10, 339362, 2006.

PUPP SPINASSÉ, Karen. Deutsch als Fremdsprache in Brasilien: Eine Studie über kontextabhängige unterschiedliche Lernersprachen und muttersprachliche Interferenzen. Berlim: Peter Lang, 2005.

RÖSLER, Dietmar. Curricular interfaces: the interaction of language and contents at University level. ForumSprache, v. 2, n. 3, 10-15, 2006.

Pandaemonium, São Paulo, v. 25, n. 46, mai.-ago. 2022, p. 172-201 
GRILLI, M. - A abordagem CLIL na graduação em Letras/Alemão

SCHMELTER, Lars. Entwicklungstendenzen und Desiderata der bilingualen Sachfachdidaktik. In: HALlET, Wolfgang; KÖNIGS, Frank G. Handbuch Bilingualer Unterricht. Content and Language Integrated Learning. Seelze: Kallmeyer-Klett, 2013, 40-45.

SchmenK, Barbara. Challenging the language-content continuum. Some thoughts on teaching German at a Canadian university. In: ForumSprache, v. 2, n. 3, 35-43, 2010.

SIMÕES, José da Silva. A formação inicial de professores de alemão e a investigação de processos cognitivos da aquisição, da aprendizagem e do ensino de Alemão como Língua Estrangeira na Universidade de São Paulo. In: UPHOFF, Dörthe et al. 75 anos de Alemão na USP. Reflexões sobre uma germanistica brasileira. São Paulo: Humanitas, 2015, $243-$ 273.

UPHOFF, Dörthe; DEBIA, Deise Tott. O papel do ensino de língua e a passagem para as disciplinas de literatura no curso de Letras-Alemão da USP: considerações a partir de uma análise de necessidades. In: UpHOFF, Dörthe et al. (Orgs.). O Ensino de Alemão em contexto universitário: modalidades, desafios e perspectivas. São Paulo: Humanitas, 2017, 169190.

UPHOFF, Dörthe; LOBATO, Elaine Rodrigues Reis; SAFRA, Marcos Fernandes. A História do Ensino de Alemão no Curso de Letras da Universidade de São Paulo. Revista HELB, v. 8, n.1, 2014. Disponível em: https://bit.ly/3fcis5g. (12/08/2021).

UPHOFF, Dörthe; PEREZ, Juliana Pasquarelli. Caminhos da graduação em Letras-Alemão na Universidade de São Paulo. In: UPHOFF, Dörthe et al.75 anos de Alemão na USP. Reflexões sobre uma germanística brasileira. São Paulo: Humanitas, 13-24, 2015.

VOERKEL, Paul. Professores de alemão no Brasil - entre mitos e realidade. In: Anais do $2^{o}$ Congresso da Associação Brasileira de Estudos Germanísticos, 2017. Florianópolis: CCE/UFSC, 2017, 306-314. Disponível em: https://bit.ly/3f8REmi. (13/08/2021).

VOLLMER, Helmut J. Kompetenzstandards und Aufgabenentwicklung. In: KÖNIGS, Frank G.; HALlET, Wolfgang (Orgs.). Handbuch Fremdsprachendidaktik. Seelze-Velber: Klett Kallmeyer, 2010, 372-376.

WOLFF, Dieter. CLIL als europäisches Konzept. In: HALLET, Wolfgang; KöNIGS, Frank G. Handbuch Bilingualer Unterricht. Content and Language Integrated Learning. Seelze: Kallmeyer-Klett, 2013, 18-26. 